\title{
Museum Work as Part of the Present - The Past is the Present, the Present is the Past
}

\author{
Kirsi Liimatainen
}

Lilja and Olavi Sallinen set up the Mobilia Foundation in 1986 to support the operation of the commercially run Vehoniemi Car Museum and the Finnish Museum of Historical Military and Special Vehicles. In 1991, the financing of the Mobilia Foundation was transferred to public organizations when the Finnish Vehicle Administration, Kangasala municipality, the Ministry of Defence, and the Finnish Road Administration (Finnra) joined the foundation and agreed to fund a road traffic museum with a wider scope of operation. At this juncture, the Road Traffic Museum became one of the foundation's museums, joining the two earlier museums.

The three museums mentioned above merged under the common name of Mobilia in 1992. In 1994, Mobilia moved to new premises at Kisaranta, a beautiful site near Lake Längelmävesi in Kangasala, some 20 kilometres from Tampere.

In 1997 Mobilia and the Finnish Road Museum, was nominated by the Ministry of Education, the specialist national museum for road traffic. As a result Mobilia adopted a more nationwide operating strategy, with the objective of developing long-term cooperation with the most central national operators in the field. Consequently, Mobilia’s background organization network expanded. In addition, the development of new products was started, the most important of these being collections management services. Mobilia operates as a part of the
Finnish road traffic system by providing its customers with services connected with the storage, preservation and maintenance of historical material as well as with producing, presenting, and organizing historical information.

Finnra and Mobilia began developing collections management services in 1998. The project was entitled "collections hotel services". The product quickly became aligned with what its project name suggested, and Mobilia's objective was set: to offer comprehensive professional museum services for the management of the collections of the Road Administration, i.e. preservation, research, and exhibition operations. The collections hotel building to house these services was completed in 2001. The cooperation agreement concerning the management of Finnra's collections in Mobilia's col- 
94 lections hotel over the period 2001-2025 was signed in December 2000.

At the moment, Mobilia is the museum for 25 road traffic organizations. It is run as an enterprise, based on long-term customer relationships, economic profitability, and unique expertise within the road traffic sector. Mobilia is principally characterized as being: professional, customer-oriented, nationwide, and effective

\section{THE ADMINISTRATION OF ROAD-} HISTORICAL COLLECTIONS AS PART OF THE PRESENT STATE OF THE Finnish RoAd Administration

In 1999 the Road Administration and Mobilia laid down the principle that the Road Administration will concentrate all museum-related tasks and duties to the Mobilia museum. Underlying this aim was a decision to reorganize the Road Administration by dividing it into a government office responsible for commissioning work with the Finnish Road Enterprise providing road-building and maintenance services. The museum collections and related work could not be included in the key tasks of either organization.

In 2000 the Road Administration and Mobilia reached a long-term agreement on the responsibility for the care of the collections of objects and items. This permitted Mobilia to undertake sizeable investments related to the preservation of the collections. The transfer of the collections began in 2002 and the current aim is to have the material moved from its old storage places into the care of Mobilia by the end of 2004. Preparations for this transfer of the collections are carried out in the road districts, which have managed to recruit skilled personnel from among those whose previous job descriptions did not meet the needs of either the Road Administration or the Finnish Road Enterprise. Mobilia has been responsible for training the personnel in museum work.

Based on the positive experiences gained in the transfer of the collections of items and objects, preparations were begun in 2001 for the transfer of visual materials related to the history of roads. This was seen as a natural expansion of cooperation, because the historical materials were left without anyone to administer them after the organizational reform. Photographs in particular were seen as historical documents that belonged to both the Road Administration and the Finnish Road Enterprise. For Mobilia, the photographs contained a great deal of information needed in tasks related to the care of the collections, such as cataloguing and exhibiting the items and objects. A major part of the visual material consists of the above-mentioned documentation of present-day conditions.

\section{The Road Administration PHOTOGRAPHS ADMINISTRATION AND ARCHIVE PROJECT}

The administrative change in 1990 when the Road Administration was formed was chosen as chronological boundary for visual materials. Following this division, work was begun on photographs taken prior to 1990 . The objective was to transfer them into the care of Mobilia under an agreement similar to that pertaining to the collection of objects. The tasks and other forms of action required by the transfer were developed on the basis of experiences gained from the transfer of objects and items.

The work began with a survey of the extent of the material and instructions were drawn up for tasks related to the selection and stor- 


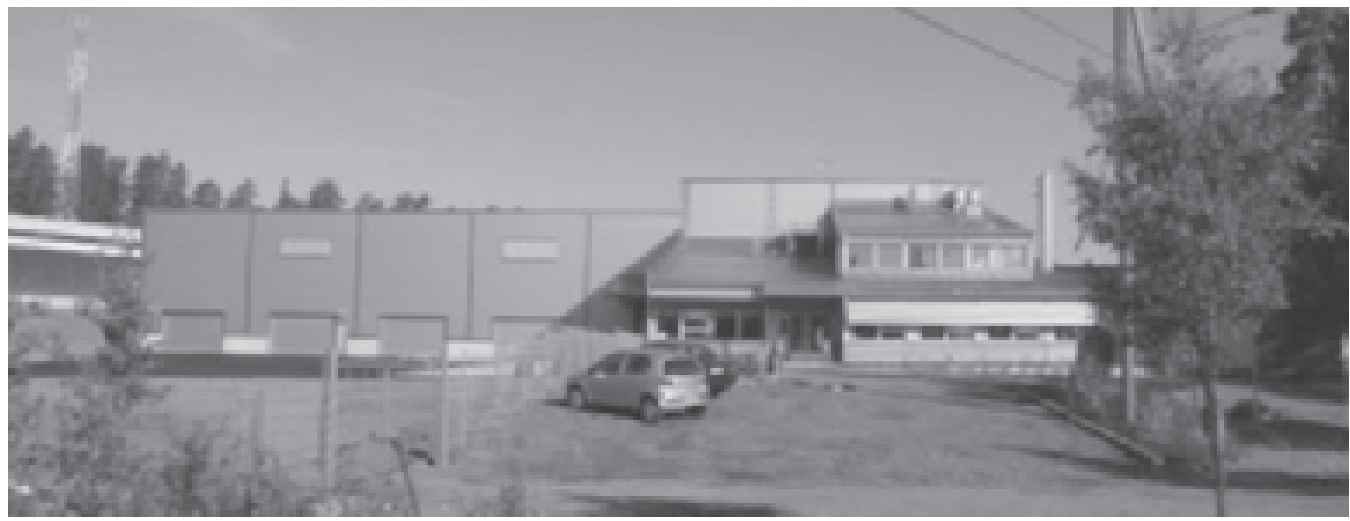

Mobilia, exterior.

age of photographs. It was also of importance for the project that the instructions and related communications underlined not only aspects of utility but also the Road Administration's official obligations under Finland's Archives Act concerning the keeping and storage of visual materials. It was estimated that there were some 160000 items of photographic material in the collections of the Road Administration.

The instructions were drawn up by the keeper of the Mobilia museum in collaboration with representatives of the central administration of the Road Administration and all the road districts. The resulting directives were circulated within the Road Administration in 2002 and implemented by training the participating representatives of the road districts to be officially responsible for organizing the selection, cleaning, documentation and packaging of the photographs in their respective districts. The objective is to have approximately $10-15 \%$ of the total photographic material permanently stored as items of high quality and high information value.

The road districts made rapid progress in preparing of the transfer of the photographs and the Central Administration and a number of road districts, for example, managed to get the material ready for transfer by spring 2003 . The transfers will be carried out during 2004 . Mobilia is preparing to receive the material not only by arranging the necessary space but also by investing in the digitization of the photographs and in a system for administering the digitized material.

During the course of the project the administration of photographs later than 1990 will also be developed to facilitate their use and to make them subsequently a part of the museum collections in a controlled manner.

\section{Digital images}

In the early 2000s the Road Administration carried out an extensive reform aimed at improving the use of all documents. Digital images were a special aspect of this project and it was noted that they occupied a major part of the available electronic storage space. It was estimated that almost 350000 digital images were stored. In addition to the considerable 


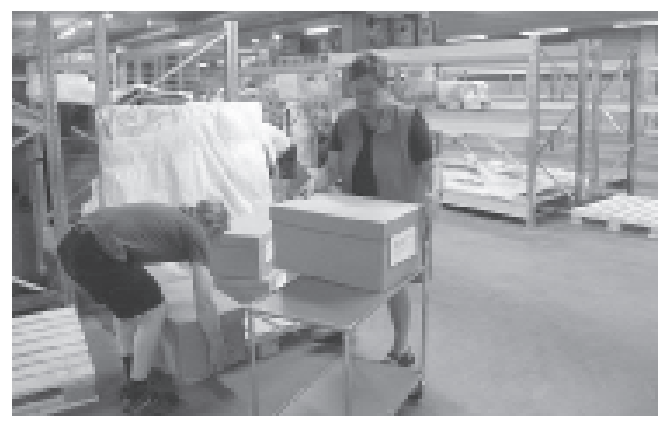

Mobilia, interior.

disk-space required for storage, a further challenge was the fact that they had limited documentation and no shared use.

It was also noted that the digital image material was growing considerably at the rate of 12500 items a month.

Museum methods are being applied to bring this situation under control. Instructions for the use and care of digital images were drawn up along the same lines as those for traditional photographs. The challenges in preparing these instructions were greater than for traditional images because there is very little experience of long-term storage of this kind of material. The instructions have therefore aroused interest among the National Board of Antiquities and other institutions involved in the archiving of photographs.

The rapid increase in digital visual material, led the project also to consider training in photography, i.e. instructions were drawn up on the kinds of photographs needed for specific purposes and how they should be transferred to long-term storage where necessary. An important aspect of these instructions was naturally the emphasis on selection.

Further development of the use and administration of digital visual material must advance quickly because it must keep abreast of the control of other documents. Moreover, the rapid growth of this photographic material is a significant economic liability. In order to implement them as rapidly as possible in practice two working versions of the instruction were drawn up as the basis for launching training during the autumn of 2003.

\section{The Benefits OF MUSEUM WORK - THE PAST IS THE PRESENT}

Over the past few years considerable amounts of money and other resources have been invested in developing the use and care of road-historical materials and in improving their storage conditions. Since 2001, some 20 people have been engaged in related projects in the Central Administration and the road districts. At the Mobilia museum the keeper, the museum technician and the collection bookkeeper have been responsible for the project.

The investment of considerable resources in developing the administration and control of historical data was made possible by an action model in which the starting point was finding a solution to the issue of the use and control of historical data belonging to the Road Administration by applying the methods of museum work. It was also important that the definition of historical data included very recent material such as digital photographs. This action model has brought together museum work and the development of the Road Administration's daily work and duties.

\section{Note}

- Leena Salejoki-Hiekkanen, Project Manager at Finnish Road Administration, and Kimmo Leva, Director of Finnish Road Museum, have assisted in the writing of this paper. 